\title{
Doing disability through charity and philanthropy in contemporary South India
}

\begin{abstract}
Drawing on multi-sited ethnographic fieldwork in Hyderabad, South India, this article explores the relationship between charity and disability. Despite a stereotype of philanthropic aid as reproductive of existing power structures or symptomatic of state failures to eliminate poverty, closer investigation exposes a more multi-layered picture. Disjunctures in donor and recipient perspectives on charity are shown to create spaces in which recipients might challenge the very characterisations that allow them access to aid in the first place, revealing both the potential and the limitations of charitable aid to bring about social change for disabled people.
\end{abstract}

KEYWORDS charity, gift, philanthropy, disability, India, Hyderabad

\section{Introduction}

This article explores, in relation to how disability was constituted and experienced by the people I worked with in Hyderabad, South India, what is sometimes referred to by disability scholars as the 'charity model' of disability: a way of understanding disability that ranks bodily anomalies alongside other forms of tragedy and, as such, identifies pity and donations of alms as appropriate responses (Coleridge 1993; Clare 2001; Miles 2002). In broad historical terms, at least in the West, such an approach enjoyed its pinnacle in the Middle Ages, an era when, as Whyte puts it: 'Infirmity and poverty were part of God's varied creation - the order of things. The response to difference was charity, spirituality, and morality.' (1995:269). Lumped into a more general 'bundle of misery’ (Stiker 1982:95) alongside poverty and other types of distress, disability had not yet been differentiated as a category, one that could be relocated, as it was during the Enlightenment, within new medical discourses. In eighteenth century Europe, religious discourse began to lose its grip on 
disease and disability, which increasingly became the domain of the anatomist, the pathologist and the doctor rather than the clergyman or the philanthropist. Disabilities became redefined as flaws measurable by positivist, objective science (Foucault 1989: 167).

Such developments might not everywhere have followed precisely the same trajectory, but the imposition of colonial medicine and, consequently, the near global hegemony of biomedicine, help to account for the comparable medicalisation of disability in Hyderabad, India's sixth largest city. Disability (vikalangulu in Telugu, or vikalang in Hindi) was framed by those I worked with as, predominantly, a medical problem, albeit one that led, as will become clear, to culturally particular forms of social exclusion and, in some cases, opportunity. Stiker and Foucault are right about the overall thrust of thinking and associated practices away from charity and on to medicine- ' the product of a shift in explanatory frameworks on the identification of a new niche', as Turner identifies it (1996: 200)—but the shift was not absolute. Charity was never fully eclipsed by medicine; particularly, as we shall see, in cases where medicine had nothing much to offer, but also because philanthropy is integral to Indian ways of being in the world (cf Ilchman et al 1998:xii).

Disability, as my interlocuters understood it, described various bodily differences that constrained them from fully achieving what might socially be expected, relative to their status, gender and age, such as marriage, work, reproduction or particular forms of mobility. It is the role of charity as a prism through which disability, as it is broadly conceived on in India, might be explored and better understood that is the focus of this article. Charity, both a set of practices and an abstract idea, is difficult to pin down. Sometimes it lurks amid notions of rights and of development; sometimes it is cited as their exact opposites, or categorised alongside theories of gifting and exchange. Charity might be part of a religious injunction to give, drawing, for example, on the Islamic duty of zakat, the payment of part of one's income to the poor (Benthall 2003:9; Bornstein 2012: 27), or the expectation on Hindus to donate food to various categories of the poor (Lewis 2004:306). The term might also be used to encompass the associated categories of philanthropy, beneficence and good deeds (Ilchman et al 1998: xii), as well as in relation to the less 
explored perspectives of aid recipients (Caplan 1999). Charitable organisations, one of the mediums through which ideas about charity are manifested, sit at one of end of a continuum loosely defined as 'civil society', occupied by a range of voluntary groups that exist separately from the state (Van Rooy 1998; White 1994; Lewis 2004). Such groups might be complementary to activities of the State, but they might also be established in opposition to it. ${ }^{1}$ The charity offered by Christian missionaries, for example, has been criticised — historically as well as more recently — by the Indian state as inappropriate inducement to religious conversion (see, for examples, Staples 2014; Kooiman 1991; Hardiman 1987; Froerer 2007; Bauman 2008).

My aim here is not to reify 'charity', but to consider how it is evoked, and to what effect, in specific ethnographic contexts. By constituting disability in relation to charity, gifting and philanthropy, I argue, various kinds of bodily differences in India produce opportunities and constraints, both for those defined by themselves or others as 'disabled' people and for those who work with them in various capacities. In making this case, I draw on 18 months' fieldwork in Hyderabad during 2005 and 2006 and subsequent shorter visits: in hospital out-patient clinics for people impaired by cerebral palsy and for the sight-impaired; at a school for the blind; with disability NGOs and activist groups; at public meetings; and in a community for variously impaired people on the peripheries of the city. My interlocuters, in addition to those self-identified as disabled, included medical professionals, bureaucrats, activists and members of a more general public, and my research technique — while grounded in participant observation — frequently incorporated in-depth, semi-structured interviews. I also draw on ongoing supplementary fieldwork, dating back to the 1990s, in a leprosy colony in coastal Andhra Pradesh.

I begin here with a story in which certain ideas about charity are made manifest, before moving on to consider how different social actors, from individual benefactors to charity workers, institutions and the recipients of charitable aid, link into elements of that story.

${ }^{1}$ Flanigan, for example, considers links between charity, political violence and terrorism (2006). 


\section{Fauzia's Tale}

Fauzia Begum's ${ }^{2}$ story, narrated by her mother Uzma Begum, is interesting less for the details of her life than the structure of her narrative and for the asides: the replies offered not in direct response to my questions but the comments slipped in between; the reiteration of key themes; and the avoidance of topics that deflected from her central storyline. It also helps set the scene for a wider discussion on the relationship between disability and charity.

I was sitting with Uzma, her husband Faisal and my research assistant, Das, in the small patch of shade thrown by the overhang of a rusty corrugated iron roof, directly opposite Uzma and Faisal's one roomed house. It was not even 9am but, this being late April, the temperature was already scorching. Uzma and her family were Muslim residents of Karimapet Colony, a cluster of around 130 houses built on land allocated by the Government to those it categorised as physically disabled people. Residents came from across religious communities, with a small Muslim majority. We had been visiting the settlement regularly for the past seven months, hanging around in tea stalls, conducting interviews, and attending community functions.

Fauzia, Uzma and Faisal's daughter, was 20. She had contracted polio as a small child and lost the use of both legs. Her father, until he became too ill to work, had pulled a cycle rickshaw. Uzma stuffed and stitched mattresses, whenever work was available, for daily wages. Certified by the Government as 100 per cent disabled, Fauzia got a meagre pension worth, at the time, Rs100 per month. She supplemented her income through begging in the markets that sprawled out from Hyderabad's main landmark, the Charminar, a few miles south of Karimapet. 'She started when she was 11 or 12,' said Uzma. 'There was no money in the house, and she wanted things that girls want: soap, hair oil, talcum powder. She wanted to be modern. Living in this place you get to know a lot of people who already go begging, so she said she wanted to go along as well. What could we do?'

\footnotetext{
${ }^{2}$ Names of people and places have been changed.
} 
Uzma's rhetorical question at this point seemed designed to distance herself from Fauzia's begging: it was, she stressed, Fauzia's own choice.

Fauzia currently went begging at least twice a week, using the tricycle she acquired (possibly from the Government, Uzma was uncertain). Her parents were cagey about how much she earned, but they allowed two of her three brothers to accompany her to push the tricycle and to protect her, so the work must have been at least relatively lucrative. Conservative estimates from others reckoned begging earned, at the time, from Rs50-Rs100 per day, more during festivals ${ }^{3}$. Uzma's work, by contrast, would earn her just Rs30-40 a day.

Uzma, though, was keener to talk about the treatment they had given her than the money she might bring in. This was, after all, a narrative of hardship. When doctors told them Fauzia could not be treated with 'English medicine' (as Uzma called it), they tried herbal remedies, including concoctions to massage into Fauzia's legs and potions to consume. 'If any one recommended anything, we took it,' said Uzma. 'If anyone suggested someone or a special place, we went there. We went to mosques that people told us were powerful, we prayed to Allah, we went to all kinds of healers.' Nothing worked. Uzma's face took on a sad expression; her eyes became moist and her voice unsteady. She raised her eyes to the sky and then back down again, patting her head with her hands. It was a common gesture of helplessness. 'All this is Allah's will,' she said. 'Only He knows how we are suffering.' Uzma's husband Faisal, who had been sitting quietly at her side until this point, chipped in that he had attempted suicide by consuming half a kilogramme of green chillies when he saw that his daughter's life had been spoiled. Then, he said, he had taken rat poison to end

\footnotetext{
${ }^{3}$ These figures also compared to those given to me by leprosy-affected people begging in the more cosmopolitan city of Mumbai, on India's west coast, a few years earlier (Staples 2007a:180). Another of my informants in 2006, who begged neared one of Hyderabad's main railway stations, put the figure rather higher, at between Rs200-300 per day.
} 
his suffering and was only here today because his family had borrowed money to get his stomach pumped. ${ }^{4}$

Seventeen years on, the current problem was finding Fauzia a marriage partner. 'Who'll want to marry her when there are plenty of healthy girls around?' questioned Uzma. 'She can cook, if you put everything out for her, she can manage to get herself dressed, go to the bathroom. She can do most work, but she can't carry pots of water, do the sweeping or the other kinds of heavy work a wife is supposed to do.' She went on: 'Then sometimes, going to the toilet, she can't move herself properly and her clothes become soiled. And because she's a girl a man can't help her, and I have no other daughters so it falls on my head to help her, to clean her up, to comfort her. What can we do?' Answering her own question about who would be prepared to take on such a girl, Uzma told me that there were families in the community who would accept her, but 'we want a good boy, someone who will take care of her. I don't want to marry her off to a drinker or a drug user. I don't want to spoil her life. And that's what's difficult.'

I learned later, from other members of the extended family, that Uzma's own husband, Faisal, had taken a polio-disabled woman-Uzma's younger sister, as it transpired—as his second wife when Uzma failed to conceive in the first years of their marriage. Uzma had subsequently had four children and Faisal now lived exclusively with her. It was not, I suggest, a detail that fitted well into Uzma's narrative. Although this kind of alliance between disabled women and able-bodied men — which I saw several examples of elsewhere during my research—illustrates possibilities open to disabled woman, perhaps it was precisely this kind of arrangement that Uzma was hoping to avoid for her own daughter. Nevertheless, marriage remained the ultimate goal. Fauzia's future care depended upon it.

\footnotetext{
${ }^{4}$ See Staples 2015, 2012a \& b, and Staples \& Widger 2012 for more on the context of such suiciderelated behaviours in India.
} 
I recall Uzma's telling of her daughter's story here because it was a common one. Details of the impairments changed, but most framed disability within a discourse of sickness and included similar accounts of the treatment trail. Most stories were also accounts of hopes—of cure, of marriage - and fears of what might happen after the parent dies. And what an even greater number of these stories have in common was their inbuilt cry for outside help. Sometimes it was implicit but more often, as in Uzma's narrative, it foreshadowed the whole account. Throughout the story, Uzma emphasized her family's material poverty, alongside the cost of treatments and aids that might assist her daughter. She also stressed her own hardship: no daughters to help her, and a husband — despite his dramatic displays of distress — who offered little practical support. These elements are interwoven into every stage of the story. Even when a question did not offer an obvious opportunity, she would end her answer with a reference to how only Allah knew how much she had suffered. At the end of the story, she offered a supplementary account of how her daughter was currently undertaking hospital treatment for jaundice and how much it was costing. She asked if I could contribute Rs $100 .^{5}$

Although Uzma's request made me feel uncomfortable, it did not take me by surprise. Almost every interview we had conducted with families of disabled people - across social boundaries — ended with a variation on the same question: how can you help us? It came from affluent Hindu families wanting medical contacts in US hospitals so they could investigate help for

\footnotetext{
${ }^{5}$ I had a stock response to these requests. I said I would give Rs30 as compensation for the time she had spent talking to me - the amount agreed at the start of the interview-but that I would not give handouts for other things. This payment strategy was intended to keep the relationship as an exchange (time for money), rather than to establish myself as a patron on whom further claims could be made. Whether this was successful is debateable.
} 
their daughter, and it came from others who, like the grandfather of a small girl who could not walk or speak, wanted to know how the information he had just given me would be translated into a possible cure. Such requests were different to Uzma's, but they all illustrate how requests for help for disabled family members are legitimated in a way that other kinds of requests are not. There are several possible explanations for this, as emerged through discussions with my interloctors, disabled as well as able-bodied. While for Hindus disability might be associated with karmaretribution for sins in a past life, or a lesson for the current one-it was not usually seen as indicative of more immediate personal failings in the way that, for example, poverty might be. It might also, as I shall demonstrate, be taken as a signal of specifically positive qualities, including those of sacrifice, endurance and inspiration. As valued qualities, requests for help could thus be presented, at least implicitly, as opportunities for donors to accrue merit as much as for the recipient to acquire aid. While this capacity to ask for help did not always equate to a call on charity, it certainly established 'the disabled' as a category of the needy and opened this up as a particular possibility. For those for whom it was accepted that there was no cure, it was sometimes seen as the only possibility. Fauzia's begging and her mother's direct request for funds were acceptable, from the family's perspective, because her lack of personhood - exemplified by the difficulties they encountered in trying to find a marriage partner-left no other choices. In short, disability in South India created the right to ask for help and, with it, a space within which to receive charitable gifts.

This brings me to a related point, one that mirrors Helander's (1995) argument that sickness and disability are, in many contexts, conflated. This was certainly so for those I met in out patients' clinics and, to a lesser extent, in the school for the blind. Treatment constituted an arduous journey that frequently preoccupied carers of young disabled people long after diagnosis. This, argues Helander, is important because, once cure is no longer seen as a plausible end-result, particular kinds of personhood might also be given up on. Among the Hubeer of Somalia, he suggests, when attempts to restore health do not work, a disabled person 'appears permanently incapacitated and cut off from the stream of life' (1995: 74). Personhood, for the Hubeer (and for many South Indians 
too) is 'never a given, never completed', but is 'an array of continuously shifting influences' (1995:

76). Given what is often presented in the literature as the relative fluidity of South Asian selves ${ }^{6}$, families' unwillingness to accept a terminal identity of 'disabled' for their offspring is unsurprising. As Das and Addlakha note, disability in India is located not only in individual bodies, but is dispersed more widely within social and kin relationship networks (2001: 512; see also Mehrotra 2011: 71). An endless search for a cure also allows hope that the defective person will one day achieve something akin to full personhood.

When a disabled identity is accepted as terminal, however, aspirations to personhood are either scaled back or given up altogether (Whyte 1995: 274). In Fauzia's case, it was the near impossibility of her becoming what her family saw as a socially complete woman — despite continued attempts to find her a husband - that positioned her as an obvious recipient of charity. Without marriage or children, and without the capacity to contribute to the family in socially conventional ways, her personhood remained incomplete. The 'medical model', in short, gives way to the 'charity model' as a framework for understanding her social position. Within the latter, impairments sometimes become undifferentiated from other forms of misery and suffering, and thus deserving of pity (Stiker 1982: 95ff, cited in Whyte 1995:269). And this is where Uzma was pitching Fauzia and, by association, the rest of her family during our conversation: as potential recipients of my mercy.

We will return to frame Uzma and Fauzia's experiences alongside those of other beneficiaries of charity shortly, as well as the broader political context in which charity is enacted. First, however, I want to shift our focus from beneficiaries to those whose attention Uzma and others like her were keen to attract: charitable donors and their organisations.

\footnotetext{
${ }^{6}$ For a summary of these arguments, see Staples (2003) and, for the background to them, Mines (1988), Marriott (1976, 1989), Busby (1997), Lamb (1997), Parry (1991) and Spencer (1997).
} 


\section{Donors: Big Men and Benefactors}

All sorts of people ran small charitable institutions in South India, for multiple reasons (Caplan 1999). Many I encountered over the past 30 years, however, fell into one of what I categorise as two groups: rural Christian converts, from relatively poor, agricultural backgrounds; and middle-class, affluent Hindu professionals and business people from various caste backgrounds. ${ }^{7}$ For the former group, running an organisation was aspired to because it could provide upward social mobility, offering economic opportunities, prestige and spiritual salvation. Orphanages, children's charities or medical organisations offered potentially lucrative and status-enhancing links with overseas donors, larger NGOs and government officials.

'That's what I should have done,' Das, my research assistant, once told me, regretfully. 'Started some kind of small, service organisation. A hostel, maybe, where you just do everything in one place: provide meals, accommodation and education. It's a good service, you make some money to live on, and the whole family has somewhere to stay.' His fantasy had been brought on by a visit to a hostel run by a mutual contact, Mariamma. It had taken her nearly 20 years of saving to build a modest brick and cement dwelling for her family, but since she had turned the place into an orphanage, starting with just four children, her fortunes had changed dramatically. She had met an American Protestant evangelist at local prayer meetings who had agreed to help her and, once she had obtained permission to receive foreign contributions from the Government, had attracted a regular income for her registered charitable organisation. She had built an additional storey on her house, now used as bedrooms for the 30 children who had come to live there, and had bought, among other things, an automatic washing machine and a water purifier. She was also able to employ two ayahs and a cook, while her grown-up daughter served as a matron. Mariamma had

\footnotetext{
${ }^{7}$ There were, of course, organisations run by other groups, including Muslims (Benthall and Belliou-Jourdan 2003), Parsis (Luhrmann 1996:105-107; White 1991) and Anglo-Indians (Caplan 1999).
} 
become the female equivalent of a local 'big man' (Mines 1994), a status further demonstrated by her running, albeit unsuccessfully, for the elected office of Municipal Chairman during my earlier fieldwork in 2000. As Caplan puts it: 'While not all philanthropists engage in community politics, all those with political power must engage in philanthropy' (1999: 296). She worked hard and provided a service that was well received by the local community. In bringing up those in her care as Christians she also, in her view, fulfilled spiritual obligations.

It is into this context of local organisations that several of the disability organisations I encountered, particularly those in rural areas, slotted. I explored one such NGO in detail elsewhere (Staples 2007c). Other NGOs, like the urban blind school where I conducted research more recently, fitted better into my second category: organisations set up by those who have already been successful in business, often Hindus, and who also - like Mariamma — have spiritual obligations to meet.

For Hindus, dana — or giving — is considered part of one's dharma (moral duty). Parry (1986), in his classic critique of Mauss (1954), explores this further, focussing on the danadharma gift, an offering made to Brahmins to direct 'badness' away from the giver. As such, 'the unreciprocated gift becomes a liberation from bondage to it, a denial of the profane self, an atonement for sin, and hence a means to salvation' (1986: 468). Contrary to the received wisdom, he argues, not all gift relationships are ideally reciprocal; some of them, indeed, are intentionally and necessarily one directional. Parry was referring specifically to the danadharma gift when he made this point, but it is useful for thinking about the gifts made by charitable organisations and the individuals who ran them — a point also developed by Bornstein (2012:41). These gifts were similarly unreciprocated but were made to the needy, not the Brahmin. Precisely because the recipients were unable to repay their benefactors, a relationship of dependency could be established, 
with the donor accruing merit. ${ }^{8}$ Although many of those I worked with were not Hindus—-so drew on alternative and additional framings of charity and philanthropy — the pervasiveness of Hinduism in the Indian context meant that even those who did not subscribe to it as a religion could scarcely prevent their worldviews being shaped, at least to some extent, by its ideologies and practices.

It was not just classical Hindu theology that was significant here. Many of the middle-class Hindu philanthropists I worked with were drawn to what Kent (2004) describes as 'Sai Baba rhetoric' (2004: 52): that is, the teachings of the guru Sai Baba, especially popular among middle class South Indian Hindus, and also well-known to many Christian converts I encountered. While classical Hinduism focuses on renunciation as a route to salvation (Dumont 1970), Sai Baba emphasises the need for people to fulfil their dharma by dedicating themselves to others. As Kent explains:

Sai Baba's updated delivery of Hinduism makes no demand that people relinquish all their worldly acquisitions. On the contrary, he makes it possible and even desirable for them to maintain their prosperity. He simply provides a way to reconcile this with spirituality through an inner, emotional transformation brought about by devotion, love and charity' (2004: 53).

This teaching, unsurprisingly, appeals to India's affluent classes across religious boundaries, enabling them to 'manage prosperity without forfeiting their spirituality' (Kent 2004: 60). By

\footnotetext{
${ }^{8}$ As Anand (2004) sets out, from a classical Hindu perspective there are four principle motivations for giving alms: to acquire punya (merit) in order, ultimately, to attain Moksha (liberation); prayaschita (acts of repentance); aparigriha (the principle of non-accumulation of wealth); and/or karuna (compassion). While the first two entail self-interest, the latter two motivations appeal to a notion of selfless duty. While my informants were more nuanced in their interpretations of scripture, there was no doubt that many embodied ideas derived from it. See also Juergensmeyer and McMahon (1998), who cite Kare's (1941) rendition of passages from the Rig Veda on the benefits of charitable giving.
} 
giving, donors accumulate spiritual capital and fulfil their dharma without subordinating themselves to the recipients of their gifts.

Icons of Sathya Sai Baba—easily spotted because of his distinctive afro hairstyle and saffron robes_-featured prominently at the blind school and at other charitable organisations I worked with, his philosophy sitting well with the aspirations of their founders. Dr Sai Prasad, founder of the blind school, was a good example. A successful ophthalmologist with his own private practice, he could fulfil his obligations — and enjoy the accolades of others — without having to give up the material comforts he had spent his working life accumulating. The cups, certificates and framed photographs of himself with various dignitaries that lined the shelves of his office - as well as the list of awards and honorary degrees that filled his business card—also served as material evidence of the worldly respect such service gave.

'I need to make sure my own family is provided for.' Dr Sai Prasad told me. 'If we're going to be able to give service, we need to be in a good position ourselves first, don't we?' His comment mirrors the Sai Baba approach. This was nevertheless a difficult line to tread. In the case of other organizations that I encountered, the commitment to service sometimes appeared to serve selfinterest in a rather more direct way. Dr Anjanilu, the founder of a much larger disability service organization, was disparaged by some of my informants as 'only interested in making money.' These informants, mostly middle class, were likewise interested in making money, but what they objected to in Dr Anjanilu's case was that he did so in the name of service. 'You see, his organization is run as a business,' one parent of a cerebral palsy affected child told me. 'When we stopped going to his private clinic, using his medicine, he wasn't interested in letting us come to the rehabilitation centre any more. He makes money from it, he gets collections and donations from outside, and he gets tax incentives too.'

These kinds of accusations were common against many organizations I worked with over the years. As Mines and Gourishankar note: 'The bigger a leader becomes and the more he appears to benefit from his status, the more vulnerable he becomes to accusations of venality and corruption' 
(1990:763). Such accusations about motives — and the fact that people of a certain stature wanted to be involved with such organizations - suggest that disability is a special category that exists outside the rules of usual business. To provide educational or rehabilitation services to the disabled, within this rubric, is - to quote from the visitors' book at the blind school—a 'divine act', not one on par with the worldlier provision of economic goods, even when disabled people paid for the services on offer. The disabled, then, offer a route towards salvation, as a distinctive category of the needy, regardless of their economic circumstances. This meant that work with disabled people accrued greater merit than work with the general population, as noted previously, but it also left one open to harsher criticism if material gain was understood to be the principal motivation for such work.

'An institution is the lengthened shadow of one man,' Sai Prasad once told me, quoting the American essayist Ralph Emerson (1841, in Atkinson 2000), suggesting that his school was also a concrete representation of his values, a projection of himself. Although Sai Prasad looked West for his supporting quotation, his perspective on institutions was also continuous with Indian conceptions:

Institutions in India are... personalized to an extent inconceivable in the West; individuals who head them are believed to be the sole repository of the virtues and vices of the institutions; as human brings, such individuals in authority are thought to be accessible to appeal, open to the impulse of mercy and capable of actions unconstrained by the rule of the 'system'. (Kakar 1981:40-41, cited in Mines and Gourishankar 1990: 764).

There were also Gandhian influences at play here. While Gandhi alluded to the classic Hindu notions of dan and seva (service), and might even have exposed them to a wider audience, he also gave them his own twist. Gifts, as tributes aimed at enhancing the giver's power, were transformed into philanthropy (Juergensmeyer and McMahon 1998: 268). In this sense, Sai Prasad was also 
following a trail blazed by the likes of the well-known Birla family ${ }^{9}$, who gained a reputation for building temples, hospitals and schools (ibid: 269).

The organizations I have described here are more than their founders, however, vital though an undertstanding of their motivation is to an exploration of how philanthropy and charity help to constitute disability as a category. By looking more closely at the day-to-day running of the blind school, both from the perspectives of staff and of the students, in the next section I want to consider more closely the relationship between service organizations and disability.

\section{The Blind School}

For Gracie Johns, the Christian head teacher of Sai Prasad's blind school, her contribution, like my social worker friend Mariamma's, was governed by 'God's calling.' Describing how she took up the job after teaching in a mainstream school, she said: 'I wanted to do something worthwhile after my retirement. When I saw the children, it was really love at first sight [...] I felt that God guided us into this institution, and that this job was tailor made for me and for [my husband]. Both our talents are utilised here to the maximum.' In addition to a strong link between the work and her Christian faith, she was also clear that the job gave her 'emotional fulfilment'. Here, again, we see work with disabled people as imbued with higher moral qualities than work in other contexts: although Mrs Johns had a paid role in the school, at a comparable rank to that she had held elsewhere, her present position was constituted as a charitable act.

The post also made her the gatekeeper for others who wished to contribute to the school, offering her a unique perspective on the growing list of film actors who came to share their birthday cakes and bestow other gifts in the company of press photographers and camera crews. Speaking to me on the morning of a visit from a locally well-known actress, she told me:

'It's a craze now for these film actors to want to celebrate their birthdays with the disabled [...]. I suppose it generates some good publicity for them, makes them more popular, and, well, if it

\footnotetext{
${ }^{9}$ One of India's wealthiest trading families.
} 
does some good - raises some more awareness - than that is also good, no? [...] I try to strike a balance. Film stars and their like feel good when they come and do something for the children. But we want consistent consideration for the children: compassion, not pity. And we should be able to teach and follow the usual routines. We've had people, even grown men, like an army officer who visited us, who cry when they see the plight of these children. And that can upset the children. But their eyes should still soften, and so should their voices and their touch! When people touch us lightly we feel the gentleness, but when people are harsh and raise their voices we feel darkness.'

On the morning of the actress's birthday celebration, the film studio had sent an entourage ahead of her arrival to cover the walls of the first-floor meeting room-a space built specifically for these purposes — with red, heart-shaped balloons. By the time her car pulled up outside, the school children, the press and the anthropologist were already waiting in the room. Events began with a dance display from some of the older children, based on a routine from one of the actress's recent films, and were followed by the presentation of a huge cake, supplied by the film studio. The actress then cut the cake and to fed slices to a selection of students as journalists took photographs. Small boxes containing sweet meats, savouries and cartons of mango juice, were distributed to each child. Photographs of the actress's visit — depicting her feeding a slice of cake to one of the children-appeared in some newspapers the next morning, and the story was also covered by a local news channel. The children got to meet one of their heroines and to partake of special edibles; the actress got to boost her profile. And the children, like Fauzia, were represented as needy and worthy of help.

\section{A Hierarchy of Disabilities}

It is not difficult to find pragmatic motivations for the episodes of unreciprocated gifting described above, nor to link them to wider ideas about philanthropy in India. What is interesting, though, is why the actress, and many others, chose the blind school over a wide range of other charitable 
causes. Not all disabilities, or the specific contexts in which they were enacted, were considered equally worthy of charitable assistance.

Blindness, for example, had a specific appeal for high profile donors. For a start, many people considered it to be the worst of all bodily conditions ${ }^{10}$. 'They live in darkness,' one man told me. 'They can never see the beauty of the world.' Although this was a view less prevalent among my sight-impaired respondents, it was a condition that people felt they could empathise with.

Bodies that did not repel, that evoked sadness and pity but not disgust and fear, clearly held the most appeal for formalised charitable giving. Donors could empathise with those who appeared as damaged versions of themselves rather than as radically different: those who moved and spoke in familiar ways, or those with bodies shaped in ways that conformed to expectations of the average body. The sight impaired fitted this description well. Those with less acceptable bodies, like those with the balloon-sized hands and fingers of elephantiasis, or the nose-less faces of untreated leprosy, appealed at a different register. Such bodies were particularly effective in street begging, for example, as my own research with leprosy-affected beggars has shown (Staples 2007b: chapter 8). Donors paid up quickly to banish such perceived monstrousness from their lines of vision. 'In this way', as Murphy phrases it, 'the able-bodied lull their consciences without getting too close; they stress their own separation and wholeness by an act of charity' (1995:153).

Blindness, then, when it was not accompanied by other bodily anomalies, was less challenging to personhood than conditions that remodelled the body or changed the way it moved. Consequently, it appeared seductively unambiguous. Photographs of children with closed together eyelids and a white stick were more readily iconic of neediness than comparable images of a children with cerebral palsy, dribbling and moving their limbs with an unpredictability that outsiders found unsettling. The blind person's day-to-day personhood remained largely intact in

\footnotetext{
${ }^{10}$ As was apparently the case in other parts of the world, too, such as Uganda (Sentumbwe 1995) and Barbados (Goerdt 1984).
} 
ways that it did not for people with other bodily differences. To be sure, looking at the sight impaired could also be problematic, as the case of the army officer reduced to tears illustrates. But images of the blind nevertheless offered an uncomplicated message. Blindness deserved pity, and those who gave it were good.

In common with a loss of limbs, blindness could also be attributed to noble causes. An elderly man I knew, for example, was revered as the victim of a hand grenade attack during the independence struggle of the 1940s. Having lost both eyeballs in the incident, he consequently introduced himself as a 'freedom fighter': his blindness served as a symbol of his sacrifice. ${ }^{11}$ As someone who had subsequently obtained a university education and worked as a lecturer, he also fulfilled another role sometimes popular among high profile donors: that of what disability activists sometimes critique as the 'supercrip.' The 'supercrip', to use Berger's definition, is one 'whose inspirational stories of courage, dedication, and hard work prove that it can be done, that one can defy the odds and accomplish the impossible' (2004: 798). The well-chronicled problem with the 'supercrip' stereotype, of course, is that it creates unrealistic expectations of what people might be able to achieve, and suggests that they should be able to achieve certain things if only they put in sufficient effort. Both the problem of disability and its solution, then, is located within the individual disabled person rather than in society (cf Berger 2004; Shapiro 1993; Wendell 1995; Tighe 2001; Tierney 2001).

Unlike Fauzia, whose polio-deformed limbs combined with her gender made her appear helpless, pupils at the school offered that very kind of inspiration. Many of them, for example, had

\footnotetext{
${ }^{11}$ Of course, had the struggle for independence from the British turned out differently, his injuries might have been subject to another reading. While the severely wounded soldiers of post-revolution Nicaragua described by Bruun are cast positively as 'symbols of the revolution' (1995:197) and as 'heroes to the public' (ibid:206), maimed warriors elsewhere were unwelcome reminders of warfare gone wrong (French 1994).
} 
come from poor, uneducated families, and yet, through their schooling, had achieved top grades in state exams, won national chess championships and even dance competitions. For a donor, such results were rewarding: they offered the 'warm glow' sometimes associated with gifting, and sidestepped the idea — popular among disability activists — that disability is a consequence of structural violence rather than individual bodily failing. Gifts to people whose bodily differences meant they were less likely to succeed in conventional terms likewise avoided such social model definitions of disability, but they yielded less of a return. As Gracie Johns put it in relation to her own motivations: 'Blind people I can help, I can pass on what is in my head. But I couldn't do that with mentally retarded people...I wouldn't know how to help them. It is not my calling, either.'

The fact that pupils at the school were children was also significant, and their capacity, as incomplete human beings, to fulfil the 'supercrip' stereotype was related to this. Children were characterised as naturally more vulnerable, needy, and worthy of assistance: 'Children cannot speak for themselves,' read one of the many signboards at Dr Anjanilu's centre for the disabled. 'We must speak for them.' Unlike adults, they also had more potential to change (cf Priestley 2003: 62) and even be cured. ${ }^{12}$ Young adults, like Fauzia, or the older leprosy-affected people I worked with in coastal Andhra, were considered beyond major transformation and, therefore, appropriate recipients for only certain types of aid.

It was not just these associations with blindness that appealed to high profile donors, however. Context was also vital. The school in question was conveniently located-from the perspective of film stars and the press — in an easily accessed, affluent location near the centre of the city. As a school, it was also suitably bounded: it had a bureaucratic structure through which to give donations, and it even had a room for VIPs in which ritualised public gifting could take place (cf Mosse 2005: 127). Gifting to a community like Karimapet, where Fauzia lived, was, by contrast,

\footnotetext{
12 Priestley (2003:69-70) notes how disabled children in classical English fiction routinely either recover or die: to enter adulthood as disabled appears unacceptable.
} 
more complicated. There were no structures through which money could communally be received; the community was geographically marginal; and it was far less hospitable as a venue.

Different donors, too, were attracted to different causes. While headline-grabbing bodiessuch as those with AIDS/HIV - might appeal to those in the public eye, a disease like leprosy, with its Biblical connotations and links to missionary endeavour had a resonance for Christian donors. ${ }^{13}$ In short, while there was no rigid hierarchy of disabilities, each set of negatively construed bodily differences were considered separately and in context, some of them considered more deserving than others of charitable aid at different times and places. The question now facing us, then, is where this left the recipients of such philanthropy. It is to this that we now turn.

\section{Recipients}

'The idiom of the gift,' Mosse tells us, 'is a public fiction that gets around the harsh facts of power and economic asymmetries' (2005:128-129). In his Pedagogy of the Oppressed, Paulo Freire goes even further: 'To have a continued opportunity to express their "generosity",' he writes, 'the oppressors must perpetuate injustice as well. An unjust social order is the permanent fount of this "generosity", which is nourished by death, despair, and poverty' (cited in Farmer 2005: 153-154). In some ways, the story with which I began this article-Uzma's tale of her daughter Fauzia's reliance on begging - is indicative of these inequalities. If Fauzia was not denied the chance to make a reasonable living in another way, if Uzma was paid a decent wage for stitching mattresses or had been trained in something more lucrative, and if there was a welfare state that genuinely compensated for the family's economic and bodily disadvantages, Fauzia would not have had to go begging, I would probably have had less access to their narratives, and Uzma would not have had to ask me if I could spare Rs100. Charity, as Barnes and Mercer point out, 'provides an enduring cultural message that helps perpetuate an image of helplessness and dependency' (2003: 26).

\footnotetext{
${ }^{13}$ See, for examples of this, Bailey (n/d, 1890) Cochrane (1927), Bridson (1951), Staples (2007a:154-157).
} 
Begging, in that its success depends on cultivating such a stereotype of the disabled body, helps to maintain the status quo.

Nevertheless, there is more to Uzma's story than, to use Marx's term, the 'sigh of the oppressed creature' (Marx 1884, trans. Livingstone and Benton 1975), unable to understand or resist the structural violence inherent in her position. Neither can their acceptance of dependence on charity as a natural outcome of being disabled be explained solely through the notion of a false or 'double consciousness' (Du Bois 1986). It is quite possible, for example, for people to embrace systems of power at the same time as they resist them (Abu-Lughod 1990:43). The leprosy affected people who I continue to work with offer a good illustration of this. In many cases they accepted negative representations of themselves self-consciously in order to reap a net advantage, while in other contexts their struggles for resources led them to subvert the symbols of constraining institutions (Staples 2007a: 10). The same might also be true of Uzma's situation. The story she told was, after all, a particular representation; one crafted to elicit maximum sympathy and, she hoped, financial gain. For Fauzia, anyway born into poverty, her disability in some ways gave her more agency, not less. If she was prepared to engage with negative stereotypes of a disabled body, her polio-affected legs offered a right to ask - in the eyes in the public if not in statute - that was not automatic for those with 'normal', but still deprived, bodies. Such engagement did not, however, mean that she accepted or internalised that stereotype. Ravi, another polio-affected man I knew, who begged each morning outside the railway station near my house, explained how the use of his body in this way could actually be generative of self-respect. Chasing statutory benefits, by contrast, was considered potentially demeaning:

I'm not interested in begging, it's not what I want to do. But it is an opportunity provided to me because of my handicap, and so I've taken it. If I go to the Government and ask them for help or for a pension, they'll only ask me for bribes, so I've not asked for anything. I've done it my way. These arguments follow a path charted by Scott (1990) and his recognition of 'weapons of the weak' as a partial counter to Gramscian hegemony, since reworked by several analysts who have 
used ethnographic material to nuance accounts of power and resistance (eg Dube 2004; Ortner 1995; Abu-Lughod 1990; Mendelsohn and Baxi 1994). Such arguments offer important insights into the agency of those who, like Uzma and Fauzia, rely on charitable donations for their livelihoods. However, that agency needs to be understood within the broader context of their marginalisation. In accepting images of themselves as inferior and in need of help, even when, like Uzma, they do so pragmatically to gain material advantage, they lock themselves into existing power structures, where certain categories of people are dependent on the beneficence of others. 'It's up to the big people to look after us in these situations,' as one man, the father of a cerebral palsy disabled small boy, expressed it in a conversation with me. An elderly Parsi philanthropist I had got to know, Mrs Billimoria, was sponsoring his son's treatment. 'We thank the Gods for her and for her help,' he told me. 'We aren't educated like you or her; we need to follow behind like a goat follows her herder.'

The agency of disabled people, as the above quotation illustrates, was certainly shaped and, ultimately, limited by their material impoverishment. It was also shaped by the kind of charity on which they were dependent. Begging, for example, involved instant, usually short relationships with random individual donors met on the street. Although some beggars spoke of regular donors, there was a large transient population on which they could draw, and so no obligation to accept particular rules of behaviour, as might be laid down by State or NGO donor agencies. That marked its appeal for someone like Ravi, who remained independent in a way he could not have been had he relied on institutions (or, indeed, employers) for his sustenance.

The gifts offered through institutions, like the breakfast boxes blind children received from the actress, bound the beneficiary much more closely into an unequal relationship with the donor. It was a relationship all too often mediated by pity. 'People have been affectionate and loving,' conceded Anusha, a partially sighted girl who I met when she was brought to the eye hospital I visited by a medical charity. 'But they don't even ask me to do the things that I can do.' The mother of a boy who attended the blind school offered a similar sentiment: 'People tend to show too 
much sympathy,' she said, 'when what they want is to be treated like equal citizens.' Her comments were echoed endlessly in the responses students at the school gave to a question I asked about how people reacted to their differences.

They were not criticising the school itself; rather, the public attitudes towards blindness and other bodily differences that both necessitated charity and provided it. Paradoxically, it was also the school, in which the children sometimes found themselves on the receiving end of pity, that had empowered them to see this in ways that Uzma, say, could not. Classes designed specifically to bolster their self-confidence and to challenge the received wisdom on disability, alongside rigorous adherence to the State's curriculum and training in Braille, enabled them to enter training and to obtain jobs that would not otherwise have been open to them. This was not charity in the conventional sense that I have been describing it. It did not perpetuate their dependency but, on the contrary, challenged it. Those graduating from the school became self-supporting in ways that they almost certainly would not have done had they stayed at home or attended conventional schools. And while independence might itself be a peculiarly Western, neo-liberal goal of development, it remains in stark contrast to 'charity model' constructions of disability. What is interesting in this case, however, is that the funding for this process of self-enlightenment required alms collection and giving of a more traditional nature. The students' ultimate independence required a suppression of that independence during their school years in order that it might be financed. Unreciprocated gifts now meant they would not be necessary in the future.

The boundaries between charitable gifts, the investment of development aid and the promotion of self-sustainability, or even between State entitlements, earnings and other gifts, were, as the above suggests, often blurred. This was particularly so from the perspective of recipients. Uzma, for example, could not remember if Fauzia's tricycle was provided by the Government or by a philanthropist, and the source of her occasional State disability pension was likewise unclear, personally associated with those who delivered it. For Uzma's family, the source of the money was not important. Others showed a similar ambivalence to distinctions drawn between different types 
of income, as illustrated by the following example. Many of the sight impaired people I met at the eye hospital on a particular visit had been brought there in a minibus hired by an organisation which, according to the social worker who had accompanied them, had used Government funding to set up the self-help groups (SHGs) of disabled people of which they were all members. The visit was aimed at getting them free eye checks and, if necessary, medical attention. None of those I spoke to in the waiting room, however, had much idea about the organisation or that they were part of an SHG. 'We were brought here by that man from some charity,' said one patient, vaguely, when I asked him to explain. 'I'm not sure what they're called, but they help raise money for us disabled people in the village. They tried to get us to join their savings scheme, and sometimes you can take a loan.' Benefits offered as alternatives to charity were often interpreted by those who received them as charity, while charitable gifts were sometimes re-interpreted as rights.

\section{Conclusion}

‘...[A] peculiar combination of caring and dominance, of generosity and property, of tangled rights in things and people, all in a time and place where the strong would not let the weak go under, except sometimes.' (Feierman 1998)

Feierman was referring here to what he termed 'kindly help' in pre-colonial Africa, but he might as well have been describing some of the contradictions of charitable giving that have emerged through this article. While charity might be demonised as symptomatic of the failure to eliminate poverty (eg Poppendieck 1999), existing as much for the aggrandisement of donors as for the welfare of recipients, this is clearly too simplistic a conclusion (Farmer 2005:154).

Charity is difficult to pin down because it has different meanings and implications depending on where one stands in relation to it and how it is invoked and engaged with, and seldom neatly conforms to its definition as the contrary of development and empowerment. The enactment of charity through the making of a donation or by establishing an institution through which charitable funds will flow, for example, might help to create for donors a particular reputation that will aid them politically and/or in business, or set them down the path towards spiritual liberation. 
For low caste Christian converts, charitable institutions provided a route to prestige that was not contingent on ritual purity or birth-ascribed status. These consequences for donors bear no automatic relationship with the consequences of the same donation for either the recipients or, in the cases I have been describing, for disabled people as a general category.

Donations to the school for the blind, then, might be motivated by pity for blind children as helpless victims of the worst kinds of bodily conditions (indeed, the flow of funds towards them is in large part dependent on that very stereotype), but it is those very same donations, utilised by the institution and its recipients in a particular way, that allows sight-impaired beneficiaries to become independent, materially wealthier, and less willing to accept their categorisation as inferior or as victims than they would otherwise have been. At the same time, given the success of those who leave the school in finding college places and employment in mainstream, middle class jobs, public notions of what it is to be blind might also be expected to shift, albeit slowly, in ways that might find more favour with disability activists than with philanthropic donors.

Such a shift, however, has important implications for the beneficiaries of aid, as well as fallout for those working in the charitable sector. 'If we make them independent, what will there be left for us to do?', as one development professional said — apparently in all seriousness — in response to his colleague's (and my informant's) suggestion for improving a disability rehabilitation programme. For the beneficiaries of aid, the consequences could be even more serious. The cured but now elderly and physically disabled leprosy affected people I worked with in coastal Andhra Pradesh, for example, were suffering the consequences of a decline in funds available to leprosy aid agencies that had been brought about by the World Health Organisation's (WHO) declaration that the leprosy problem had been resolved (Staples 2004; 2007d). Yet for many of the disabled people I worked with who had not benefited from organisations like the school for the blind, alms remained a vital source of income. Ensuring that income stream continued thus required disabled people to use their bodies as marketable commodities (cf Featherstone 1991), presenting themselves as helpless even when they are not. Although, as I have argued, this affords 
physically disabled people with a certain agency, there is a catch. They need to continue playing the negative roles ascribed to them by society: beggars need to appear destitute, blind children helpless, and so on. And as long as they fulfil these roles, or, even when they do not, are imagined into them, the kind of social change that generations of children trained through the school for the blind might bring about looks unlikely to happen.

\section{References}

Abu-Lughod, Lila. 1990. 'The romance of resistance: tracing transformations of power through Bedouin women.' American Ethnologist 17(1): 41-55.

Atkinson, B. 2000. The essential writings of Ralph Waldo Emerson. New York: Modern Library Classics.

Bailey, Wellesley. C. n.d. The Lepers of Our Indian Empire: A Visit To Them In 1890-91. London: John F. Shaw $\&$ Co.

Barnes, C. and G. Mercer. 2003. Disability. Cambridge: Polity Press.

Barnes, Colin. 1992. Disabling Imagery and the Media: An Exploration of Media Representations of Disabled People. Belper: British Council of Organisations of Disabled People.

Bauman, C. 2008. Christian identity and Dalit religion in Hindu India, 1868-1947. Michigan: Eerdmans Publishing Limited.

Benthall, J. and Belliou-Jourdan, J. 2003. The Charitable Crescent: Politics of Aid in the Muslim World. London: I. B. Tauris and Co Ltd.

Berger, R. 2004. 'Pushing Forward: Disability, Basketball, and Me'. Qualitative Inquiry 10(5): 794-810.

Bridson, T. 1951. Lightening the Leper's Load. London: Salvationist Publishing and Supplies.

Bruun, Frank Jarle. 1995. 'Hero, beggar, or sports star: negotiating the identity of the disabled person in Nicaragua'. In Disability and Culture, edited by Benedicte Ingstad and Susan Reynolds Whyte, 196209. London: University of California Press. 
Burghart, Richard. 1993. 'His lordship at the cobblers' well'. In An anthropological critique of development: the growth of ignorance, edited by Mark Hobart, 79-99. London: Routledge.

Busby, Cecilia. 1997. 'Permeable and Partible Persons: A Comparative Analysis of Gender and Body in South India and Melanesia'. The Journal of the Royal Anthropological Institute 3(2): 261-278.

Caplan, Lionel. 1999. 'Gifting and receiving: Anglo-Indian charity and its beneficiaries in Madras'. In Tradition, Pluralism and Identity: In Honour of T. N. Madan, edited by V. Das, D. Gupta and P. Uberoi, 283-305. New Delhi: Sage Publications.

Clare, E. 2001. 'Stolen bodies, reclaimed bodies: disability and queerness'. Public Culture 13 (3): 359-365.

Cochrane, R. G. 1927. Leprosy in India: A Survey. London: World Dominion Press.

Coleridge, Peter. 1993. Disability, liberation and development. Oxford: Oxfam Publishing.

Das, Veena \& Renu Addlakha. 2001. 'Disability and domestic citizenship: voice, gender, and the making of the subject'. Public Culture 13(3): 511-531.

Du Bois, W. E. B. 1986. Dusts of Dawn. New York: Library of America.

Dube, Saraubh. 2004. Stitches on Time: colonial textures and postcolonial tangles. Durham \& London: Duke University Press.

Dumont, Louis. 1970. Homo Hierarchicus: the caste system and its implications. London: Weidenfeld and Nicholson.

Farmer, Paul. 2005. Pathologies of Power: Health, Human Rights, and the New War on the Poor. Berkeley: University of California Press.

Featherstone, Michael. 1991. 'The Body in Consumer Culture'. In The Body: Social Process and Cultural Theory, edited by M. Featherstone, M. Hepworth \& B. S. Turner, 170-96. London: Sage Publications.

Feierman, S. 1998. 'Reciprocity and assistance in precolonial Africa'. In Philanthropy in the world's traditions, edited by W.F. Ilchman, S.N. Katz \& E.L. Queen, 3-24. Bloomington, IN: Indiana University Press. 
Flanigan, S.T. 2006. 'Charity as Resistance: Connections between Charity, Contentious Politics, and Terror'. Studies in Conflict and Terrorism 29(7): 641-655.

Foucault, Michel. 1989. The Birth of the Clinic. London: Routledge.

French, Lindsay. 1994. 'The Political economy of injury and compassion: amputees on the Thai-Cambodia border'. In Embodiment and Experience, edited by T.J. Csordas, 69-99. Cambridge, Mass.: Cambridge University Press.

Froerer, Peggy. 2007. Religious division and social conflict: the emergence of Hindu nationalism in rural India, Social Science Press: New Delhi.

Goerdt, A. 1984. Physical Disability in Barbados: A Cultural Perspective. Ann Arbor: University Microfilms.

Hardiman, David. 1987. The coming of Devi: Adivasi assertion in western India. New Delhi: Oxford University Press.

Helander, B. 1995. 'Disability as Incurable Illness: Health, Process, and Personhood in Southern Somalia'. In Disability and Culture, edited by B. Ingstad and S.R. Whyte, 73-93. Berkeley: University of California Press.

Ilchman, W.F., Katz, S., N and Queen, E.L., eds. 1998. Philanthropy in the world's traditions. Bloomington: Indiana University Press.

Ingstad, B. and Whyte, S.R., eds. 1995. Disability and Culture. Berkeley: University of California Press.

Juergensmeyer, Mark and McMahon, Darrin, M. 1998. 'Hindu philanthropy and civil society'. In Philanthropy in the world's traditions, edited by W.F.Ilchman, S. Katz, and E.L. Queen, 263-278. Bloomington and Indianapolis, IN: Indiana University Press.

Kent, A. 2004. 'Divinity, Miracles and Charity in the Sathya Sai Baba Movement of Malaysia'. Ethnos 69(1): 43-62. 
Kooiman, D. 1991. 'Conversion from slavery to plantation labour: Christian mission in South India (19 ${ }^{\text {th }}$ century)', Social Scientist 19(8-9): 57-71.

Lamb, Sarah. 1997. 'The Making and Unmaking of Persons: Notes on Aging and Gender in North India'. Ethos 25(3):279-302.

Lewis, David. 2004. 'On the difficulty of studying "civil society": NGOs, state and democracy in Bangladesh'. Contributions to Indian Sociology 38(3): 299-322.

Livingstone, R. \& G. Benton. 1975. Karl Marx: Early Writings. London: Pelican Books.

Luhrmann, T.M. 1996. The good Parsi: the fate of a colonial elite in a postcolonial society. Cambridge, Mass.: Harvard University Press.

Marriott, McKim. 1976. 'Hindu Transactions: Diversity without Dualism'. In Structure and Change in Indian Society, edited by Bruce Kapferer, 109-142. Philapdelphia: Institute for the Study of Human Issues.

---. 1989. 'Constructing an Indian Ethnosociology'. Contributions to Indian Sociology (N.S) 23: 1-39.

Mauss, Marcel. 1954. The Gift: forms and functions of exchange in archaic societies. London: Routledge and Kegan Paul.

Mehrotra, Nilika. 2011. 'Disability Rights Movements in India: Politics and Practice'. Economic and Political Weekly 46(6): 65-72.

Mendelsohn, O. \& U. Baxi, eds. 1994. The Rights of Subordinated People. Delhi: Oxford University Press. Miles, Miles. 2002. 'Disability on a different model: glimpses of an Asian heritage'. Journal of Religion, Disability and Health 6(2-3): 89-108.

Mines, Mattison and Vijayalakshmi Gourishankar. 1990. 'Leadership and Individuality in South Asia: The Case of the South Indian Big-man'. The Journal of Asian Studies 49(4): 761-786.

Mines, Mattison. 1988. 'Conceptualizing the Person: Hierarchical Society and Individual Autonomy in India'. American Anthropologist 90(3): 568-579. 
- - 1994. Public Faces, Private Voices: Community and Individuality in South India. Berkeley: University of California Press.

Mosse, David. 2005. Cultivating Development: an Ethnography of Aid Policy and Practice. London and Ann Arbor MI: Pluto Press.

Murphy, Robert. 1995. Encounters: The Body Silent in America. In Disability and Culture, edited by B Ingstad and S.R. Whyte, 140-158. Berkeley: University of California Press.

Ortner, Sherry B. 1995. 'Resistance and the problem of ethnographic refusal'. Comparative Studies in Society and History 37(1): 173-193.

Parry, Jonathan.1986. 'The Gift, the Indian Gift and the "Indian Gift". Man 21(3): 453-473.

- - - 1991. 'The Hindu Lexicographer? A Note on Auspiciousness and Purity'. Contributions to Indian Sociology (N.S) 25(2): 267-285.

Poppendieck, Janet. 1999. Sweet charity? Emergency food and the end of entitlement. New York: Viking.

Priestley, Mark. 2003. Disability: A Life Course Approach. Cambridge: Polity Press.

Sentumbwe, Nayinda. 1995. 'Sighted lovers and blind husbands: experiences of women in Uganda'. In Disability and Culture, edited by B. Ingstad and S.R. Whyte, 174-195. Berkeley: University of California Press.

Shapiro, J.P. 1993. No pity: people with disabilities forging a new civil rights movement. New York: Times Books.

Spencer, Jonathan. 1997. 'Fatima and the Enchanted Toffees: An Essay on Contingency, Narrative and Therapy'. Journal of the Royal Anthropological Institute 3(4): 693-710.

Staples, James. 2003. 'Disguise, Revelation and Copyright: Disassembling the South Indian Leper'. Journal of the Royal Anthropological Institute 9(2): 295-315. 
- - . 2004. 'Delineating disease: self-management of leprosy identities in South India'. Medical Anthropology 23(1): 69-88.

---. 2007a. Peculiar People, Amazing Lives. Leprosy, Social Exclusion and Community Making in South India. Delhi: Orient Longman.

-- - 2007b. Livelihoods at the Margins: Surviving the City. Walnut Creek, CA: Left Coast Press.

- - . 2007c. 'When things are not as they seem: untangling the webs that hold together a South Indian NGO'. In Negotiating Boundaries and Borders: Qualitative Research On, In and For Development, edited by M. Smith, 131-153. London: Elsevier.

-- . 2007d. 'The "leper" and the State in South India'. Economic and Political Weekly 42(5): 437-443.

- - . 2012a. 'Suicide in South Asia: Ethnographic perspectives'. Contributions to Indian Sociology 46 (12): 1-28.

- - . 2012b. 'The suicide niche: Accounting for self-harm in a South Indian leprosy colony'. Contributions to Indian Sociology 46 (1-2): 117-144.

- - . 2014. 'Putting Indian Christianities into context: biographies of Christian conversion in a leprosy colony. Modern Asian Studies 48(4): 1134-1159.

- - . 2015. 'Personhood, agency and suicide in a neo-liberalising South India'. In Suicide and Agency: Anthropological perspectives on self-destruction, personhood and power, edited by Ludek Broz and Daniel Muenste, 27-46. Farnham: Ashgate.

Staples, James and Tom Widger. 2012. 'Situating suicide as an anthropological problem: Ethnographic approaches to understanding self-harm and self-inflicted death'. Culture, Medicine, and Psychiatry 36 (2):183-203.

Stiker, Henri-Jacques. 1982. Corps infirmes et sociétés. Paris: Aubier Montaigne. 
Tierney, S. 2001. 'A Reluctance to be Defined "Disabled". How Can the Social Model of Disability Enhance Understanding of Anorexia?'. Disability \& Society 16(5): 749-764.

Tighe, C. A. 2001. " "Working at Disability": a qualitative study of the meaning of health and disability for women with physical impairments'. Disability \& Society 16(4): 511-529.

Turner, Bryan S. 1996. The Body and Society: Explorations in Social Theory. London: Sage Publications.

Van Rooy, A. 1998. Civil Society and the aid industry. London: Earthscan.

Wendell, S. 1995. The rejected body: feminist philosophical reflections on disability. New York: Routledge and Kegan Paul.

White, D.L. 1991. 'From crisis to community definition: the dynamics of eighteenth century Parsi philanthropy'. Modern Asian Studies 25: 303-320.

Whyte, Susan Reynolds. 1995. 'Disability between discourse and experience'. In Disability and Culture, edited by B. Ingstad and S.R. Whyte, 267-291. Berkeley: University of California Press. 